\title{
Ecologically Safe Process for Sulfo-Aluminizing Steel Parts
}

Plyatsuk L. D. ${ }^{1}$, Tarelnyk V. B. ${ }^{2}$, Kundera Cz. ${ }^{3}$, Radionov O. V. ${ }^{4}$, Gaponova O. P. ${ }^{1}$

${ }^{1}$ Sumy State University, 2 Rymskogo-Korsakova St., 40007 Sumy, Ukraine;

${ }^{2}$ Sumy National Agricultural University, 160 Gerasyma Kondratieva St., 40021 Sumy, Ukraine;

${ }^{3}$ Politechnika Świętokrzyska, 7 Tysiąclecia Państwa Polskiego Av., 25-314 Kielce, Poland;

4 “Ferrogidrodinamika" Ltd., 45/5 Bolshaya Morskaya St., 54030 Mykolaiv, Ukraine

\section{Article info:}

Paper received:

The final version of the paper received:

Paper accepted online:
March 3, 2018

May 28, 2018

May 29, 2018
*Corresponding Author's Address: tarelnik@i.ua

\begin{abstract}
The present technical solution refers to the field of electrophysical and electrochemical processing of parts, in particular, to the electroerosion alloying (EEA) of the surfaces of steel parts with aluminum (aluminizing) and sulfur (sulfidizing), and it can be used to treat the surfaces of heat-treated steel parts in order to increase their hardness, wear resistance, to prevent frictional seizure and improve the resistance to atmospheric corrosion. When aluminizing steel parts with the use of the method of electroerosion alloying (EEA) by aluminum electrode at discharge energy $W_{p}=0.52-6.8 \mathrm{~J}$ and productivity of $1.0-3.0 \mathrm{~cm}^{2} / \mathrm{min}$, before the EEA process by an aluminum electrode, to the surface of the part to be aluminized, there is applied a consistency substance containing sulfur and aluminum powder, and thereafter, not having waited for drying of the consistency substance, the process of aluminizing by the EEL method with an aluminum electrode is carried out, and the consistency substance should have the aluminum powder content of not more than $56 \%$. There have been carried out metallographic and durametric analyses of the features of the surface layers made of carbon steels after simultaneous aluminizing and sulfidizing them by the EEA method. It is shown that the structure of the layer consists of three portions, namely, a "white" layer, a diffusion zone and a base metal. Such qualitative surface layer parameters as thickness, "white" layer and transition zone microhardness values, and also roughness increase with increasing discharge energy. The "white" layer continuity for all the investigated discharge energies of $W_{p}=0.52,2.60$ and $6.80 \mathrm{~J}$ is $100 \%$.
\end{abstract}

Keywords: electroerosion alloying, ecological compatibility, surface layer, aluminizing, sulfidizing, microstructure, microhardness.

\section{Introduction}

To date, chemical and thermal process (CTP) is one of the most effective methods for strengthening surfaces of parts to improve their durability. The main types of the CTP processes are: carburization, nitration, aluminizing, sulfidizing, cyanidation and others, which consist in simultaneously saturating a surface layer, respectively, with carbon, nitrogen, aluminum, sulfur, carbon and nitrogen, etc.

Despite the fact that the CTP technology is one of the main processes aimed at improving quality of surface layers of machine parts, it also has a number of significant drawbacks as follows: volumetric heating of a part, which results in changing its structure and initial geometric parameters (metal deformation and warps); bulky and expensive processing equipment; long duration of the process and the need in using of energy-intensive equipment, etc.

In addition, certain CTP operations are dangerous for the environment. For example, the main disadvantage of a cyanidation process is toxicity of cyanide salts and, in this regard, there is a need in special measures to provide labor protection.

In recent years, to improve the quality of machine parts surface layers, the method of electroerosion alloying (EEA), that is, the process of transferring material to a product surface by means of spark electric discharge has become increasingly important. It is characterized by the following specific features being attractive for technologists, namely: environmental safety, local action, low energy consumption, lack of volumetric material heating, strong bonding of applied material to substrate, ease of automation, and possibility of combining operations. 
In the course of the EEA process, while using different electrode materials and the environment, it is quite possible to implement the technologies being alternative to the CTP ones, but of significantly lower cost. Thus, on applying graphite electrode and saturating a surface of a part with carbon, it is possible to carry out the process of carburization; using the EEA method in nitrogen medium makes it possible to perform the nitriding process, and others.

Thus, there is a very topical problem of developing energy-efficient, energy-saving and environmentally friendly technologies to form surface layers of parts, which technologies being alternative to the CTP ones, sufficiently retaining the advantages of the CTP technologies and having no their disadvantages.

\section{Literature Review}

There is known a sulfidizing method for enriching surface layers of items with sulfur, which represents a thermo chemical process for processing items made of ironbased alloys. The effect of sulfidizing consists in creating a film of sulfides on a part surface. Sulfides increase the surface activity of metals and alloys and also provide wetting with surfactants and improve resistance to frictional seizure. The sulphide film, which has less strength than the base metal, is easily broken down at friction and separated from the base without plastic deformation, preventing the friction surfaces from frictional seizure. The film of iron sulphide (FeS) increases the wear resistance of rubbing surfaces and improves their runningin ability. The ferrosulfide coating has rather high porosity and absorbs a large amount of lubricant, providing the material with self-lubricating properties [1].

There is known a method for aluminizing surfaces of parts [2], which includes the procedures of applying an aluminum layer to a steel surface (usually by spraying), coating and annealing thereof. Spraying aluminum particles should be large, which fact accelerates the process of aluminum diffusion penetration into surface layer of metal in the course of annealing. The coating layer is continuously applied to the surface in two to three passes, and in doing so, the process should strictly follow the condition of thermal diffusion treatment to preserve the coating layer.

Having been aluminized and applied with a coating, the obtained surface layer of the part is saturated with the use of the thermal diffusion process, that is, it is annealed. The initial temperature is of 600 to $650{ }^{\circ} \mathrm{C}$, followed by rapid heating up to of 900 to $950{ }^{\circ} \mathrm{C}$ with the hold time of 2.5 to 3.5 hours, and thereafter the part is slowly cooled together with the furnace to the temperature of 500 to $550{ }^{\circ} \mathrm{C}$, and then it is cooled in the open air. The thickness of the coating applied with the use of molten aluminum depends on the temperature of the part operation. Thus, for the operating temperature of 700 to $800{ }^{\circ} \mathrm{C}$ the coating thickness is of 0.2 to $0.3 \mathrm{~mm}$, and for the operating temperature of 900 to $1000{ }^{\circ} \mathrm{C}$ it is of 0.5 to $0.7 \mathrm{~mm}$.
Having been metalized with aluminum, the part is covered with 10 to $20 \%$ aluminum chloride solution, and then it is coated with liquid glass, sprinkled with quartz sand, and dried at the temperature of $100{ }^{\circ} \mathrm{C}$. The dried part is newly coated with liquid glass and dried again. At the temperature of 600 to $700{ }^{\circ} \mathrm{C}$, the part is loaded into the furnace and heated up to the temperature of 1200 to $1250{ }^{\circ} \mathrm{C}$ with the hold time of 14 to 40 minutes, after that it is slowly cooled first in the oven to $800{ }^{\circ} \mathrm{C}$ and then in the open air.

Along with the above said positive results, the technology described has a number of drawbacks. Those are the followings: high cost and labor intensity of the process, the need in control at all the technology stages, inevitability of heating the entire part, and accordingly, the presence of structural changes in the metal, deformations and warps, the process duration is more than 8 hours, high power consumption, negative impact on the environment, etc.

In accordance with publication [3], using the method for providing electrospark depositions of titanium on aluminum and aluminum on titanium, there have been created coatings containing the intermetallics of Ti-Al. While applying the methods of electron microscopy, $\mathrm{X}$-ray diffraction and micro-X-ray spectroscopy, there were analyzed the structure and composition of the coatings obtained. It has been found out that, regardless of the duration and frequency of the discharge pulses, the surface layer formed in argon basically contains $\alpha-\mathrm{TiAl}_{3}$ intermetallic. The phases of $\gamma$-TiAl and $\alpha_{2}-\mathrm{Ti}_{3} \mathrm{Al}$ can be obtained by depositing aluminum on titanium followed by depositing a second layer of titanium. At creating electrospark coatings in the open air, there are additionally formed alumina and titanium nitride. This technology is also performed in a protective environment, for example, argon, and it can be used only for parts made of titanium.

The closest to the proposed method is a method for electroerosion alloying (EEA) by an aluminum electrode of steel parts at the discharge energy of $\mathrm{W}_{\mathrm{p}}=0.52$ to $6.8 \mathrm{~J}$ and productivity of 1.0 to $3.0 \mathrm{~cm}^{2} / \mathrm{min}$. The method provides for the formation of a so-called "white" (aluminized) layer, respectively, of 70 to $130 \mu \mathrm{m}$ thick having microhardness of 5000 to $7500 \mathrm{MPa}$, roughness (Ra) of 6 to $9 \mu \mathrm{m}$ and continuity of 95 to $100 \%$ [4].

It should be noted that with this treatment method, the maximum thickness values of the aluminized layers were obtained at the highest discharge energy of $W_{p}=6.8 \mathrm{~J}$, and they were equal to 70 and $130 \mu \mathrm{m}$, respectively, on the substrates made of 20 steel and 40 steel. Such thickness values are not always sufficient to protect steel part surfaces, which are exposed to high temperatures, against destructions thereof. In addition, with a dry (nonlubricated) contact of a part surface aluminized in such a way, there is a possibility of occurrence of frictional seizure, jamming, micro-welding and rupturing individual areas of the surface. 
There is known a method for sulfo-carburizing surfaces of steel parts with applying a process of electroerosion alloying by graphite electrode, wherein a consistency sulfur-containing substance has been applied to the steel surface just before alloying with a graphite electrode [5]. The main disadvantage of this sulfo-carburizing process is the lack of possibility of protecting the part from oxidation at high temperatures (700 to $900{ }^{\circ} \mathrm{C}$ and higher), as well as from atmospheric corrosion and seawater.

Thus, the aim of the work is to create a process for aluminizing steel parts with the use of the method for electroerosion alloying by an aluminum electrode, which is devoid of the above mentioned drawbacks and which provides an increase in the hardness and wear resistance of parts preventing friction seizure and improving the resistance to atmospheric corrosion.

\section{Research Methodology}

To determine the effect of the EEA equipment energy parameters on the quality parameters of the coatings, there were made the specimens of 20 steel and 40 steel having a size of $15 \times 15 \times 8 \mathrm{~mm}$, where on a consistency substance was applied in the form of a sulfuric ointment with sulfur content of $33.3 \%$. Before applying, the aluminum powder of the mark of PAD-0 (GOST 5494-95) had been added into the sulfuric ointment. The maximum amount of the powder was $56 \%$. Further increasing the amount of the powder resulted in decreasing its adhesion to the surface to be aluminized. After that, without waiting for drying the consistency substance, there was produced the EEA method by an aluminum electrode on the unit of "Elitron-52A" model with the use of various operating modes. Moreover, each EEL mode had its own value of discharge energy and productivity, that is, the area of the formed coating per unit of time (Table 1).

Table 1 - EEA productivity dependence on discharge energy

\begin{tabular}{|c|c|c|c|c|c|}
\hline $\begin{array}{c}\text { Discharge energy } \\
W_{p}, \mathrm{~J}\end{array}$ & 0.52 & 1.3 & 2.6 & 4.6 & 6.8 \\
\hline $\begin{array}{c}\text { Productivity, } \\
\mathrm{cm}^{2} / \min \end{array}$ & $\begin{array}{r}1.0- \\
1.3\end{array}$ & $\begin{array}{r}1.3- \\
1.5\end{array}$ & $\begin{array}{c}1.5- \\
2.0\end{array}$ & $\begin{array}{r}2.0- \\
2.5\end{array}$ & $\begin{array}{c}2.5- \\
3.0\end{array}$ \\
\hline
\end{tabular}

It should be noted that decreasing the EEA method productivity results in decreasing the qualitative parameters of the surface layer (the appearance of burns, and the most importantly, the destruction of the formed layer), which event especially occurs on 'harder' modes at discharge energy $W_{p}>1 \mathrm{~J}$. Increase in the productivity results in decrease in the continuity of a coating. As a tool electrode, there was used a $\varnothing 4$ rod with length of $45 \mathrm{~mm}$ made of aluminum wire of SvA99 GOST 7871-75 mark.
The metallographic analysis of the coatings was carried out using an optical microscope of МИМ-7 (МІМ-7) model, the durametric studies were carried out with the use of the instrument of ПМТ-3 (PMТ-3) model.

The surface roughness after EEA method was determined with the use of the profilograph-profilometer of 203 model of the Калибр (Caliber) plant production by taking off and processing the profilograms.

To study the sulfur distribution over the depth of the layer, a local micro-X-ray spectral analysis was performed, based on recording the characteristic X-ray radiation excited by the electron beam of the chemical elements, which were present in the microvolume. For this purpose, there was used an electron microscope equipped with an X-ray spectral micro-analyzer, ISIS 300 Oxford instruments.

\section{Results and discussions}

Fig. 1 shows the microstructure of the surface layer formed on the specimen made of 20 steel coated with a consistency substance containing sulfur in the amount of $33.3 \%$ and aluminum powder in the amount of $56 \%$ while performing the EEA process by an aluminum electrode at the discharge energy value of $W_{p}=6.8 \mathrm{~J}$ (a), as well as the microhardness distribution while deepening from the surface (b).

The characteristic feature of the structure is a massive "white" layer, the thickness values of which in some portions are of 160 to $200 \mu \mathrm{m}$ (Fig. 1 a). The microhardness on the surface is about $5000 \mathrm{MPa}$. While deepening, the microhardness gradually decreases and at the depth of $170 \mu \mathrm{m}$ it transfers into the microhardness of the substrate $(1700 \mathrm{MPa})$.

Figure 2 represents the profilograms of a portion of the 20 steel specimen surface sulfo-aluminized with the use of the EEA method performed by an aluminum electrode at the discharge energy of $\mathrm{W}_{\mathrm{p}}=6.8 \mathrm{~J}$.

In Table 2, there are shown the qualitative parameters of the surface layers of 20 steel and 40 steel at performing the sulfo-aluminizing process using the EEA method at the discharge energy values of $0.52,2.60$, and $6.80 \mathrm{~J}$.

The presence of sulfur in the consistency substance contributes to the sulfidizing process. In Table 3 , there is shown the sulfur content while deepening from the surface in the course of sulfo-aluminizing 20 steel with the use of the EEA method at the discharge energy of $6.80 \mathrm{~J}$.

Thus, as a result of investigation of the surface layer of the specimen made of 20 steel after sulfo-aluminizing thereof, it has been found out the coating continuity makes up $100 \%$, the layer thickness is up to $200 \mu \mathrm{m}$, and the microhardness is up to $5000 \mathrm{MPa}$. 


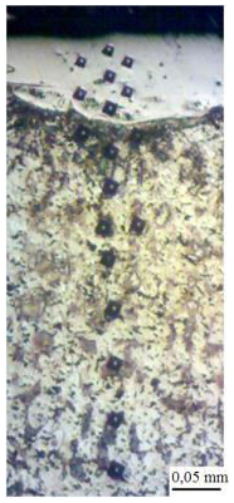

a

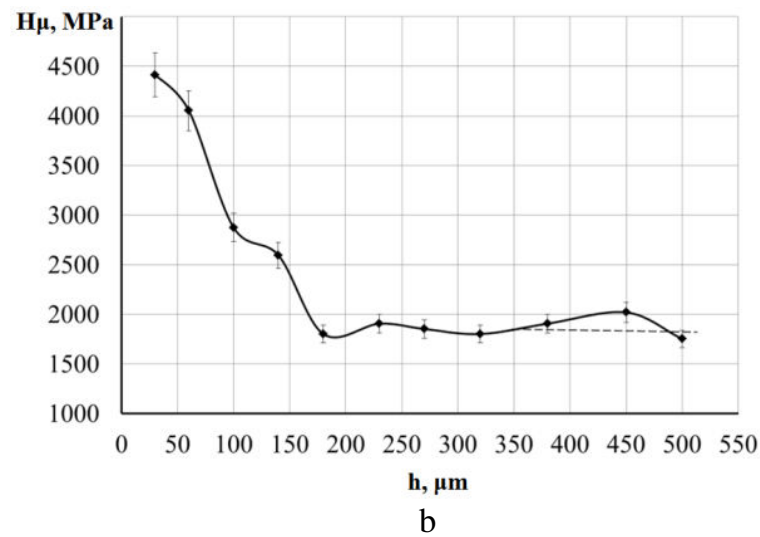

Figure 1 - Microstructure (a) and microhardness distribution in the surface layer (b)

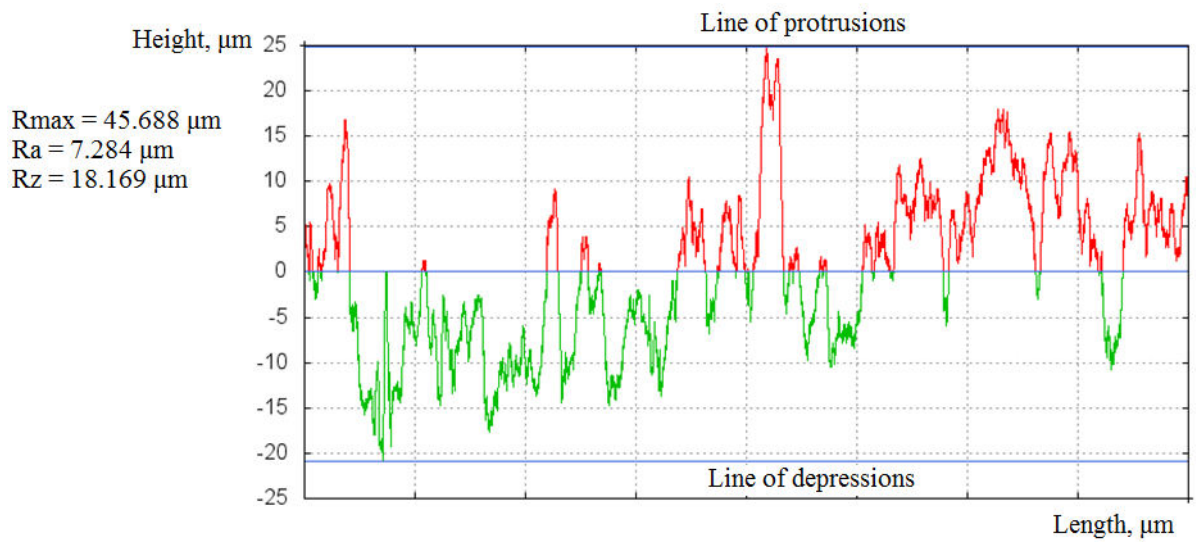

Figure 2 - Profilogram of the surface layer of the specimen made of 20 steel

Table 2 - Qualitative parameters of the surface layers of 20 steel and 40 steel at sulfo-aluminizing them using the EEA method

\begin{tabular}{|c|c|c|c|c|c|c|}
\hline \multirow{2}{*}{ Discharge energy, $\mathrm{J}$} & \multirow{2}{*}{$\begin{array}{c}\text { Thickness of white } \\
\text { layer, } \mu \mathrm{m}\end{array}$} & \multirow{2}{*}{$\begin{array}{c}\text { Micrihardness } \\
\text { of white layer, MPa }\end{array}$} & \multicolumn{3}{|c|}{ Roughness, $\mu \mathrm{m}$} & \multirow{2}{*}{$\begin{array}{c}\text { Continuity } \\
\text { of white layer, \% }\end{array}$} \\
\hline & & & $\mathrm{Ra}$ & $\mathrm{Rz}$ & $\mathrm{R}_{\max }$ & \\
\hline \multicolumn{7}{|c|}{20 Steel } \\
\hline 0.52 & $50-60$ & $3500 \pm 70$ & 1.9 & 2.9 & 8.3 & 100 \\
\hline 2.60 & $110-130$ & $4200 \pm 70$ & 3.7 & 9.7 & 25.2 & 100 \\
\hline 6.80 & up to 200 & $5000 \pm 50$ & 7.3 & 18.2 & 45.7 & 100 \\
\hline \multicolumn{7}{|c|}{40 Steel } \\
\hline 0.52 & $70-100$ & $3850 \pm 50$ & 1.7 & 3.2 & 8.2 & 100 \\
\hline 2.60 & $140-160$ & $4700 \pm 50$ & 2.9 & 3.2 & 11.5 & 100 \\
\hline 6.80 & up to 240 & $5400 \pm 70$ & 6.1 & 13.3 & 38.0 & 100 \\
\hline
\end{tabular}

Table 3 - Sulfur content while deepening from the surface in the course of sulfo-aluminizing 20 steel with the use of the EEA method at the discharge energy of $6.80 \mathrm{~J}$

\begin{tabular}{|c|c|c|c|c|c|c|c|c|c|c|}
\hline Depth of measurement, $\mu \mathrm{m}$ & 20 & 40 & 60 & 80 & 100 & 120 & 140 & 160 & 180 & 200 \\
\hline Presence of sulfur, $\%$ & 0.21 & 0.17 & 0.12 & 0.10 & 0.08 & 0.07 & 0.06 & 0.04 & 0.03 & 0.03 \\
\hline
\end{tabular}

\section{Conclusions}

The possibility of applying an environmentally friendly process of sulfo-aluminizing surface layers of machine parts by the method of electroerosion alloying has been considered. Metallographic and durametric analyses of the features of the surface layers of carbon steels after simultaneously aluminizing and sulfidizing by the EEA method have been carried out. It is shown that the structure of the layer consists of three portions, namely, a "white" layer, a diffusion zone and a base metal. With increasing the discharge energy values, such qualitative parameters of the surface layer as thickness, microhardness of the "white" layer and the transition zone, as well as roughness increase. The continuity of the "white" layer 
for all the investigated energies $W_{p}=0.52 ; 2.60$, and 6.80 $\mathrm{J}$ is $100 \%$.

The presence of sulfur in the consistency substance facilitates the sulfidizing process. While sulfidizing 20 steel by the EEL method at the discharge energy of $6.80 \mathrm{~J}$, the sulfur content decreases with deepening from the surface, and at the depth of $180 \mu \mathrm{m}$, it corresponds to its amount in the base.

The comparative analysis of the substrate effect on the qualitative parameters of the surface layer in the course of the sulfo-aluminizing process by the EEL method has exposed that in the event of 20 steel being replaced by 40 steel, the thickness of the "white" layer and the transition zone increases, i.e. there is increased the depth of the increased hardness zone, as well as the magnitude of its microhardness, while the surface roughness varies insignificantly.

For practical purposes, it is possible to recommend the sulfo-aluminizing process by the EEA method on the modes of discharge energy within $W_{p}=2.6$ to $6.8 \mathrm{~J}$ and productivity of 2.0 to $3.0 \mathrm{~cm}^{2} / \mathrm{min}$, which provide for the formation of the "white" layer thickness of 110 to $240 \mu \mathrm{m}$, the microhardness values of 4200 to $5400 \mathrm{MPa}$, the roughness ( $\mathrm{Ra}$ ) values of 3.7 to $7.3 \mu \mathrm{m}$ and the continuity of $100 \%$.

\title{
References
}

1. Zozulya, V. D., Shvedkov, Ye. L., Rovinskiy, D. Ya., \& Braun, E. D. (1990). Slovar-spravochnik po treniyu, iznosu i smazke detaley mashin. Kyiv, Naukova dumka [in Russian].

2. Yelizavetin, M. A., \& Satel', E. A. (1969). Tekhnologicheskiye sposoby povysheniya dolgovechnosti mashin. Moscow, Mashinostroyeniye [in Russian].

3. Pyachin, S. A., Burkov, A. A., \& Komarova V. S. (2013). Formirovaniye i issledovaniye elektroiskrovykh pokrytiy na osnove alyuminidov titana. Poverkhnost'. Rentgenovskiye, Sinkhrotronnyye i Neytronnyye Issledovaniya, No 6, 16-24 [in Russian].

4. Tarelnyk, V. B., Martsynkovskyy, V. S., Bilous, A. V., Gaponova, O. P., Konoplianchenko, Ie. V., Antoszewski, B., Kundera, Cz., \& Zhukov, O. M. (2017). Sposib obrobky poverkhon' stalevykh detaley. Certificate of the authorship, Ukraine, No. 119316 U, C 23 C 10/48 (2006.01) B23H 9/00, No. u201701845 [in Ukrainian].

5. Tarelnyk, V. B., Martsynkovskyy, V. S., Bilous, A. V., Gaponova, O. P., Konoplianchenko, Ie. V., Antoszewski, B., Kundera, Cz., Zhukov, O. M. (2017). Sposib sul'fotsementatsiyi stalevykh detaley. Certificate of the authorship, Ukraine, No. 119318 U, B 23 H 1/00 B 23 H 9/00 C 23 C 8/60 (2006.01), No. u201701847 [in Ukrainian].

\section{Екологічно безпечний спосіб сульфоалітування сталевих деталей}

\author{
Пляцук Л. Д. ${ }^{1}$, Тарельник В. Б. ${ }^{2}$, Кундера Ч. ${ }^{3}$, Радіонов О. В. ${ }^{4}$, Гапонова О. П. ${ }^{1}$ \\ ${ }^{1}$ Сумський державний університет, вул. Римського-Корсакова, 2, 40007, м. Суми, Україна; \\ ${ }^{2}$ Сумський національний аграрний університет, 40021 Суми, вул. Герасима Кондратьєва, 160, Україна; \\ ${ }^{3}$ Технологічний університет м. Кельце, ал. Тисячоліття Польщі, 7, 25-314, м. Кельце, Польща; \\ ${ }^{4}$ ТОВ «НПЗП « Феррогдродинаміка», вул. Велика Морська, 45/5, м. Миколаїв, 54030, Україна
}

\begin{abstract}
Анотація: Подане технічне рішення відноситься до галузі електрофізичної та електрохімічної обробки, зокрема, до електроерозійного легування (ЕЕЛ) поверхонь сталевих деталей алюмінієм (алітування) і сіркою (сульфідування) і може бути застосовано для обробки поверхонь термооброблених сталевих деталей, з метою підвищення їх твердості, зносостійкості, запобігання схоплюванню при терті і для поліпшення опору до атмосферної корозії. При алітуванні електроерозійним легуванням алюмінієвим електродом сталевих деталей 3 енергією розряду $W_{p}=0,52-6,8$ Дж і продуктивністю 1,0-3,0 см² / хв перед ЕЕЛ алюмінієвим електродом на поверхню деталі, що підлягає алітуванню, наносять консистентну речовина, що містить сірку і алюмінієву пудру, після чого, не чекаючи висихання консистентної речовини, проводять процес алітування методом ЕЕЛ алюмінієвим електродом, причому, застосовують консистентну речовину з вмістом алюмінієвої пудри не більше $56 \%$. Проведено металографічний і дюрометричний аналіз особливостей поверхневих шарів вуглецевих сталей після одночасного алітування і сульфідування методом ЕЕЛ. Показано, що структура шару складається $з$ трьох ділянок: «білого» шару, дифузійної зони й основного металу. Зі збільшенням енергії розряду зростають такі якісні параметри поверхневого шару, як товщина, мікротвердість «білого» шару і перехідної зони, шорсткість. Суцільність «білого» шару при всіх досліджених енергіях розряду $W_{p}=0,52$; 2,60 і 6,80 Дж становить $100 \%$.
\end{abstract}

Ключові слова: електроерозійне легування, екологічність, поверхневий шар, алітування, сульфідування, мікроструктура, мікротвердість 